\title{
Neoplastic Lesions in Streptozotocin-treated Rats
}

\author{
Hitoshi OKAWA and Kunio DOI* \\ Pharmacological Research Laboratory, Tanabe Seiyaku Co., Ltd., \\ Kawagishi, Toda-shi, Saitama, 335 Japan
}

(Received for publication : April 15, 1982)

\begin{abstract}
Pathological examination was carried out on 16 male Sprague-Dawley rats received single i. v. injection of $60 \mathrm{mg} / \mathrm{kg}$ of streptozotocin (SZ) at 5 weeks of age and maintained for 22 months. Insulinoma (63\%), renal adenoma (50\%), hepatocellular tumor (69\%), cholangioma (31\%) and Leydig cell tumor (56\%) were found in a high incidence, and therefore occurrence of these tumors was considered to be attributable to the treatment with SZ. In addition to these tumors, though in a low incidence, various such tumors as leukemia, reticulum cell sarcoma, mammary tumor and glioma were also found.
\end{abstract}

Streptozotocin (SZ), N-methyl-N-nitrosourea derivative of glucosamine isolated from Streptom yces achromogenes, has been known to be diabetogenic, oncogenic and oncolytic as well as to be antibiotic. It is well known that SZ induces insulinoma [4, $6,9,15,20]$ and renal tumor $[1,16,17]$ in a high incidence in rats $8-9$ months or more after single injection. However, there have been few reports on the induction of other tumors by $\mathrm{SZ}$ administration in laboratory animals.

The present communication describes the pathological findings of neoplastic and other changes in rats treated with $\mathrm{SZ}$ and survived for 22 months.

\section{Materials and Methods}

Forty-five male Jcl: SD rats 5 weeks of age (mean body weight: $175 \mathrm{~g}$ ) were injected intravenously with single dose of $60 \mathrm{mg} / \mathrm{kg}$ of SZ (Boehringer Mannheim $\mathrm{GmbH}$ ). Sixteen animals survived up to 22 months after SZ treatment were subjected to pathological examination. At the time of 11 months after SZ treatment, blood glucose values in the non-fasted state measured by a method of Momose et al. [10] were within a range of $325-428 \mathrm{mg} / \mathrm{dl}$ and body weight of the 16 animals ranged from 218 to $416 \mathrm{~g}$. These animals were sacrificed by exsanguination under ether anesthesia. Body weight and blood glucose values in the non-fasted state at the time of sacrifice were shown in Table 1. After the macroscopic examination, various organs and tissues were fixed in $10 \%$ buffered neutral formalin solution. Paraffin sections were cut and stained mainly with hematoxylin-eosin (H-E).

\section{Results}

1) Gross pathology

Main macroscopical findings were as follows. Unilateral or bilateral cataract was found in 12 of 16 animals (12/16). Solitary nodules of insulinoma $4-10 \mathrm{~mm}$ in diameter in the pancreas $(4 / 16)$, unilateral 


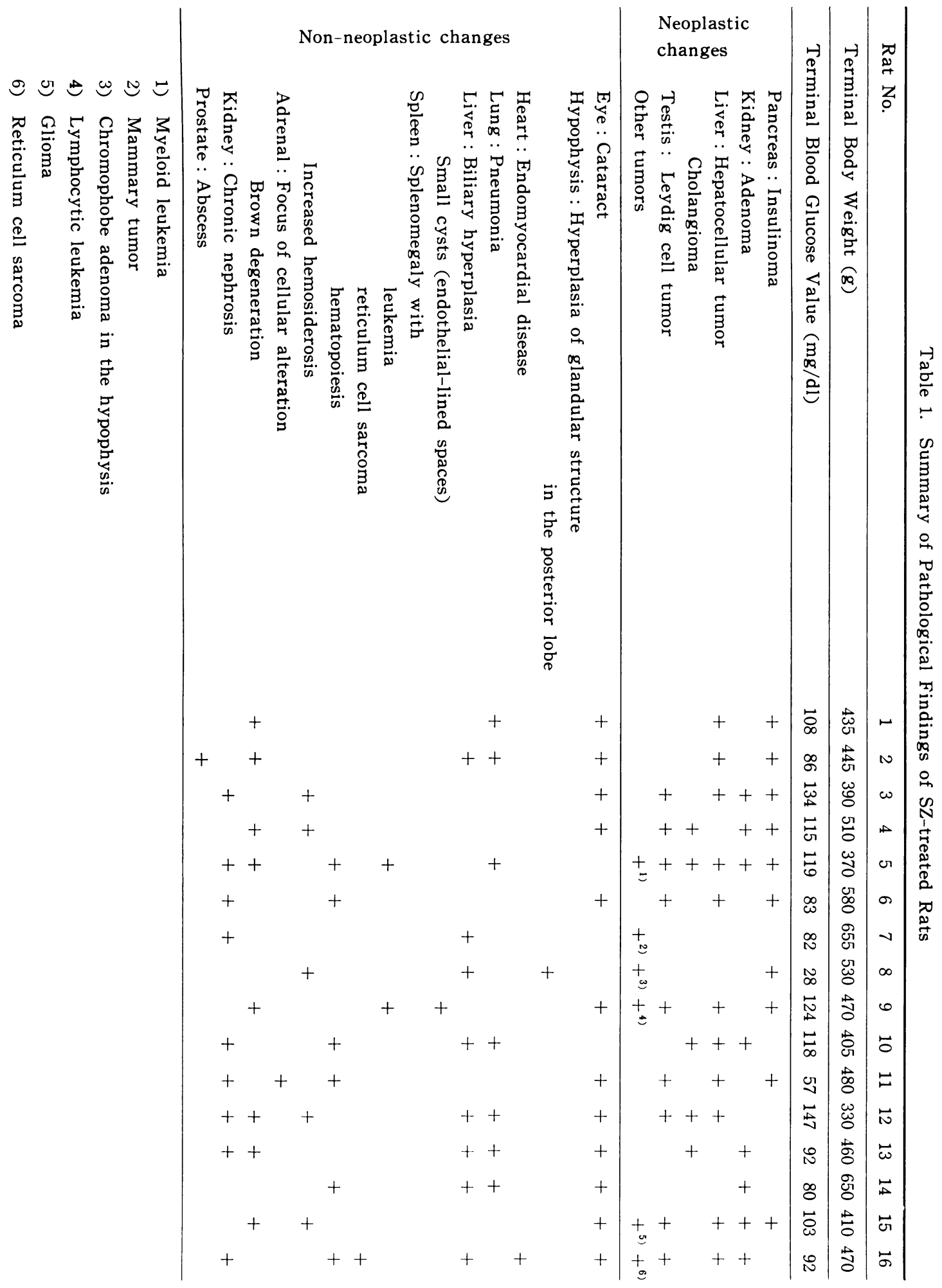


Table 2. Incidence of Various Tumors in SZ-treated and Non-treated Rats

\begin{tabular}{|c|c|c|c|c|c|c|c|c|}
\hline \multirow{2}{*}{$\begin{array}{l}\text { Report } \\
\qquad[\text { reference No.] }\end{array}$} & \multirow[b]{2}{*}{$\begin{array}{l}\text { Present } \\
\text { study }\end{array}$} & \multicolumn{4}{|c|}{ SZ-treated } & \multicolumn{3}{|c|}{ Non-treated } \\
\hline & & {$[1]$} & {$[9]$} & {$[15,16]$} & {$[5]$} & {$[11]$} & {$[13]$} & {$[14]$} \\
\hline Strain of rats & $\mathrm{SD}$ & Holtzman & Wistar & Holtzman & Lew is & $\mathrm{SD}$ & $\mathrm{SD}$ & $\mathrm{SD}$ \\
\hline Insulinoma & $63 \%$ & 5 & 86 & $4, \quad 64$ & & & 5 & \\
\hline Renal adenoma & 50 & 47 & 7 & $77, \quad 18$ & & & & \\
\hline Hepatocellular tumor & 69 & & & & 4 & 1 & & \\
\hline Cholangioma & 31 & & & & 60 & & & \\
\hline Leydig cell tumor & 56 & & & & & & 3 & 7 \\
\hline
\end{tabular}

or bilateral renal tumor $(8 / 16)$ and chronic nephrosis $(2 / 16)$, edema and formation of tumors in the testis $(8 / 16)$, hepatic nodules $(4 / 16)$ and cysts $(4 / 16)$, splenomegaly $(7 / 16)$ and tumor in the spleen $(1 / 16)$, subcutaneous tumor $(1 / 16)$ and large abscess in the prostate $(1 / 16)$ were also found.

\section{2) Microscopical findings}

The occurrence of pathological changes of individual rat is shown in Table 1 and comparison of the incidence of tumors in the present study with those in other reports is summarized in Table 2.

Pancreas : So-called insulinoma (Fig. 1) was found in 10 of 16 animals (Nos. 1, 2, $3,4,5,6,8,9,11$ and 15$)$. The size of these tumors ranged from about $1.5 \mathrm{~mm}$ to $10 \mathrm{~mm}$. The tumor occurred solitaly and well circumscribed in the most cases. Cells constituting these tumors were generally abundant in aldehyde-fuchsin positive granules (B granules), and showed almost uniform in morphology with cord-like arrangement (Figs. 1 and 2). Some of the large tumors contained several masses of cells with various characteristics, that is, the one was composed of cells having abundant B granules, showing a cord-like arrangement and the other consisted mainly of relatively large cells and irregular arrangement (Fig. 3). In addition, masses being consisted of cells with intermediate or somewhat different characteristics were found. A few non-B cells (probably A cells) intermingled with a large number of $\mathrm{B}$ cells in some insulinomas. In the nontumorous islets (so-called residual islets) of the pancreas having insulinoma, non-B cells were predominant and only a few $B$ cells were found for the most cases (Fig. 4).

Kidney : All the renal tumors were solid masses with apparent tubular structure. These were diagnosed as well-differentiated adenomas(Fig .5). Chronic nephrosis were observed in many animals.

Testis : Interstitial cell tumor (Leydig cell tumor ; Fig. 6) developed in 9 animals (Nos. 3, 4, 5, 6, 9, 11, 12, 15 and 16).

Liver: Neoplastic proliferation of the hepatocyte was observed in 11 animals. The change was divided into 2 categories according to the classification by the NCIsponsored work-shop [19]. The first was "clear cell focus or area" (Nos. 1, 2, 3, 5 and 15) (Figs. 7 and 8). The second was "neoplastic nodule" (Nos. 1, 6, 9, 10, 11, 12, 15 and 16) (Figs. 9 and 10). There were also a few intermediate or mixed type of neoplastic nodules (Fig. 11). Furthermore, cholangioma (Fig. 12) and intrahepatic biliary hyperplasia were also observed in a high incidence. A mass of small cystic structures lined by endothelial cells was found in one animal (No. 9).

Spleen : Splenomegaly was observed in 7 animals with myeloid leukemia (No. 5), lymphocytic leukemia with congestion (No. 9 ), reticulum cell sarcoma (No. 16) or int- 
ense hematopoiesis (Nos. 6, 10, 11 and 14).

Other organs : Mammary tumor (No. 7) in the ventral subcutaneous tissue, chromophobe adenoma (No. 8) in the anterior lobe of the hypophysis and glioma (No. 15) developed near the ventriculus lateralis cerebri were also observed.

\section{Discussion}

Histopathological characteristics of insulinomas and renal tumors found in the present materials were almost the same as those reported in similar experimental systems $[1,9,16,17,21]$. Concerning the pathogenesis of the insulinoma, it is possible that overloading of long lasting hyperglycemia resulted from selective $B$ cell cytotoxicity of $\mathrm{SZ}[7,8]$ stimulates a few surviving $B$ cells to proliferate actively and then brings about neoplastic alterations of these $B$ cells.

A few non-B cells intermingled with a large number of $\mathrm{B}$ cells in some insulinomas in the present materials. Yagihasi and Nagai [21] recently reported multicellularity in $\mathrm{SZ}$-induced islet tumors for the most cases based upon circumstantial condition and suggested the presence of totipotential stem cell. As another explanation, it ts possible that pre-existing non-B cells might survive in $B$ cell tumor after SZ-treatment.

In the present materials, the amount of B granules, cellular size and pattern of proliferation of islet tumor cells were not uniform. These differences may be related to the disparity in differentiation. Difference in reactivity of insulinomas against glucose loading $[4,6]$ may be related to the degree of differentiation of the tumor cells of insulinomas.

In contrast to insulinoma, most of the residual islets in the pancreas having insulinoma had non-B cells, probably A cells, as a predominant constituent. These findings may be a histological expression of secondary and adaptative change against the growth of functioning $B$ cell tumor.
Tumorous changes of liver cells, including preneoplastic "clear cell focus", seen in the present observations are not to be peculiar to SZ-treated animals but rather similar to those spontaneously occurring in aged rats [3]. Feldman et al. [5] reported induction of cholangioma by $\mathrm{SZ}$ in rats. In contrast to the results of the previous report, the incidence of hepatocellular tumors was higher while that of cholangioma was relatively lower in the present obervation. Induction of hepatoma and cholangioma by SZ was also reported by Berman et al. [2] and Sibay and Hayes [18] in Chinese hamsters.

Moreover, it is noteworthy that the incidence of intrahepatic biliary hyperplasia was relatively high in the present experiment as compared with that reported in aged Sprague-Dawley rats [12]. Berman et al. [2] reported that biliary hyperplasia was noted only in SZ-treated hamsters.

As shown in Table 2, incidence of the tumors thought to be induced by SZ, that is, insulinoma, renal tumor, hepatocellular tumor, cholangioma and Leydig cell tumor, is considerably different by authors. The animal species and strains used, length of the observation period, treatment with or without nicotinamide and dose of SZ may be important factors to its oncogenesis.

Neoplastic changes were observed in various organs other than the pancreas, kidneys, testis and liver, and causal relation between $\mathrm{SZ}$ treatment and these various tumors is to be studied. The present observation suggests that several tumors are induced in rats by single injection of SZ.

\section{Acknowledgment}

The authors thank Dr. Hajime Iwai for his kind offer of the materials, Mr. Masahiro Inagaki for his expert technical assistance and Mrs. Kinue Asai and Miss. Tomoko Kataoka for their secretarial help in preparing the manuscript. 


\section{References}

[1] Arison, R. N., and Feudale, E. L. (1967). Induction of renal tumour by streptozotocin in rats. Nature, 214, 1254-1255.

[2] Berman, L. D., Hayes, J. A., and Sibay, T. M. (1973). Effect of streptozotocin in the Chinese hamster. J. Natl. Cancer Inst., 51, 1287-1294.

[3] Burek, J. D. (1978). Pathology of aging rats In A morphological and experimental study of the age associated lesions in aging $\mathrm{BN} / \mathrm{Bi}, \mathrm{WAG} / \mathrm{Rij}$ and $(\mathrm{WAG} \times \mathrm{BN}) \mathrm{F}_{1}$ rats, pp. 58-70 CRC Press.

[4] Dixit, P. K., and Bauer, G. E. (1976). Studies on rats with islet beta cell tumors induced by nicotinamide and streptozotocin. Proc.Soc. Exp. Biol. Med., 152, 232-236.

[5] Feldman, S., Scharp, D., Hirshberg, G., Dodi, G., Ballinger, W., and Lacy, P. (1977). Streptozotocininduced liver tumors. Transplant., 24, 152-154.

[6] Frigo, I., Younoszai, R., Dixit, P. K., Matta, S. G., and Bauer, G. E. (1981). Insulin release in vitro from islet tissues and adenomas of rats treated with nicotinamide and streptozotocin : The effects of glucose. Diabetes, 30, 302-309.

[7] Junod, A., Lambert, A. E., Orci, L., Pictet, R., Gonet, A. E., and Renold, A. E. (1967). Studies of the diabetogenic action of streptozotocin. Proc. Soc. Exp. Biol. Med., 126, 201-205.

[8] Karunanayake, E. H., Baker, J. R. J., Christian, R. A., Hearse, D. J., and Mellows, G. (1976). Autoradiographic study of the distribution and cellular uptake of $\left[{ }^{14} \mathrm{C}\right]$-streptozotocin in the rat. Diabetologia, 12, 123-128.

[9] Kazumi, T., Yoshino, G., Fujii, S., and Baba, S. (1978). Tumorigenic action of streptozotocin on the pancreas and kidney in male Wistar rats. Cancer Res., 38, 2144-2147.

［10］百瀬 勉・向井良子・河辺節子(1961). 血糖および尿糖の 新定量法とその精度, 臨床検查, 5, 107-111.
[11] Morii, S., and Fujii, T. (1973). Spontaneous tumors in Sprague-1)awley JCL rats. Exp. Anim., 22, 127138.

[12] Muraoka, Y., Itoh, M., Maeda, Y., and Hayashi, Y. (1977). Histological changes of various organs in aged SD-JCL rats. Exp. Anim., 26, 1-12.

[13] Muraoka, Y., Itoh, M., Yamashita, F., and Hayashi, Y. (1977). Spontaneous tumors in aged SD-JCL rats. Exp. Anim., 26, 13-22.

[14] Prejean, J. D., Peckham, J. C., Casey, A. E., Griswold, D. P., Weisburger, E. K., and Weisburger, J. H. (1973). Spontaneous tumors in Sprague-Dawley rats and Swiss mice. Cancer Res., 33, 2768-2773.

[15] Rakieten, N., Gordon, B. S., Beaty, A., Cooney, D. A., Davis, R. D., and Schein, P. S. (1971). Pancreatic islet cell tumors produced by the combined action of streptozotocin and nicotinamide. Proc. Soc. Exp. Biol. Med., 137, 280-283.

[16] Rakieten, N., Gordon, B. S., Beaty, A., Cooney, D. A., and Schein, P. S. (1976). Modification of renal tumorigenic effect of streptozotocin by nicotinamide : Spontaneous reversibility of streptozotocin diabetes. Proc. Soc. Exp. Biol. Med., 151, 356-361.

[17] Rakieten, N., Gordon, B. S., Cooney, D. A., Davis, R. D., and Schein, P. S. (1968). Renal tumorigenic action of streptozotocin in rats. Cancer Chemother. Rept., 52, 563-567.

[18] Sibay, T. M., and Hayes, J. A. (1969). Potential carcinogenic effect of streptozotocin. Lancet $i i, 912$.

[19] Squire, R. A., and Levitt, M. H. (1975). Report of workshop on classification of specific hepatocellular lesions in rats. Cancer Res., 35, 3214-3223.

[20] Volk, B. W., Wellman, K. F., and Brancato, P. (1973). Fine structure of rat islet cell tumors induced by streptozotocin and nicotinamide. Diabetologia, 10, 37-44.

[21] Yagihashi, S., and Nagai, K. (1981). Immunohistochemical and ultrastructural studies on rat islet cell tumours induced by streptozotocin and nicotinamide. Virchows Arch. A, 390, 181-191.

\title{
Streptozotocin 投与ラットにみられた腫瘍性病変
}

\author{
大川仁・土井邦雄 \\ 田辺製薬株式会社薬理研究所
}

$60 \mathrm{mg} / \mathrm{kg}$ の streptozotocin (SZ) を 5 週齢時に単回 静注後 22 ケを経過した SD 系の雄ラット16匹の病理学 的検索を行った。その結果，インスリノーマ(63\%), 腎臓の腺腫 $(50 \%)$, 肝細胞腫瘳 $(69 \%)$, 胆管腫 $(31 \%)$ および精巣の間質細胞腫（56\%）が高率に発生した。こ
れらの腫瘍は, その発生率の高さからみて, SZ の投与 に関係して発生したものと考えられた。この他，白血 病, 細網細胞肉腫, 乳腺腫瘍および神経膠腫など種々の 腫場の発生を認めた。 


\section{Explanation of Figures}

Fig. 1. Large-sized insulinoma (No. 6). Note cord-like arrangement of tumor cells. H-E stain. $\times 150$.

Fig. 2. Large-sized insulinoma (No. 6) consisted of cells with abundant B granules. Aldehyde-fuchsin-trichrome (AFT) stain. $\times 150$.

Fig. 3. Border area of two masses of cells with abundant B granules (right half) and cells with a few or no B granules (left half) in a large-sized insulinoma (No. 6). AFT stain. $\times 300$.

Fig. 4. Residual islet (No. 3) composed of predominantly non-B cells with a few $B$ cells (arrowhead). AFT stain. $\times 300$.

Fig. 5. Renal tumor (No. 3) showing an apparent tubular structure. Remaining normal tissue (right $1 / 3$ ) is compressed by tumor mass. $\mathrm{H}-\mathrm{E}$ stain. $\times 150$.

Fig. 6. Leydig cell tumor (No. 3). Compressed and somewhat degenerated seminiferous tubules are seen in right $1 / 3$ of the picture. H-E stain. $\times 150$.

Fig. 7. Clear cell area in the liver (No. 1). Boundary between a mass of altered hepatocytes and normal tissue is apparent. H-E stain. $\times 150$.

Fig. 8. Clear cell area in the liver (No. 5). H-E stain. $\times 150$.

Fig. 9. Neoplastic nodule in the liver (No. 15). Boundary between nodule (left 2/3) and normal tissue is not so apparent. H-E stain. $\times 150$.

Fig. 10. High power view of Fig. 9. Note large nucleus and nucleolus of tumor cells. A mitotic figure (arrow) is seen near the boundary. H-E stain. $\times 300$.

Fig. 11. Neoplastic nodule in the liver (No. 6) composed of clear cells with empty cytoplasm and cells with somewhat eosinophilic cytoplasm in a random arrangement. $\mathrm{H}-\mathrm{E}$ stain. $\times 150$.

Fig. 12. Cholangioma (No. 12). H-E stain. $\times 150$. 

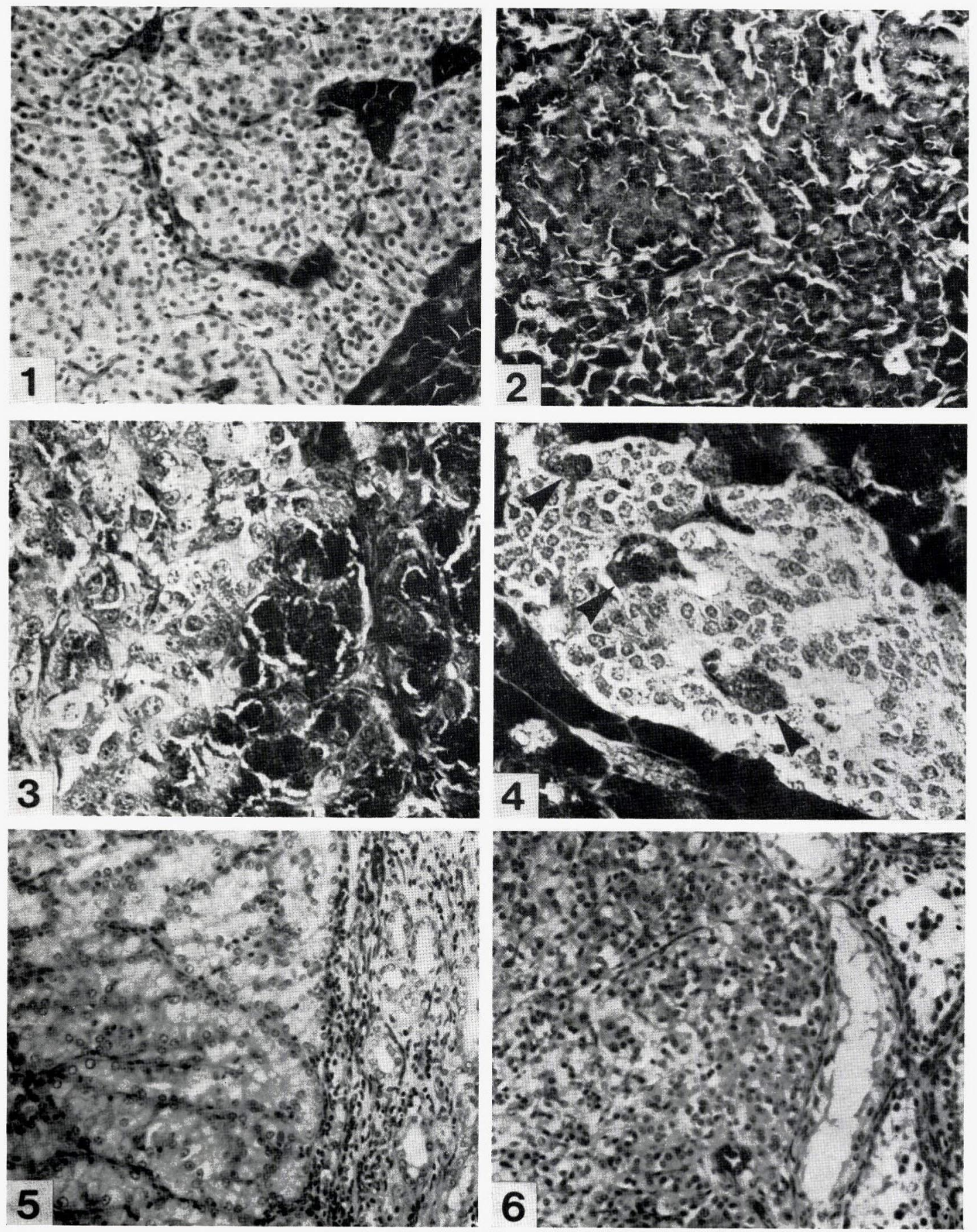

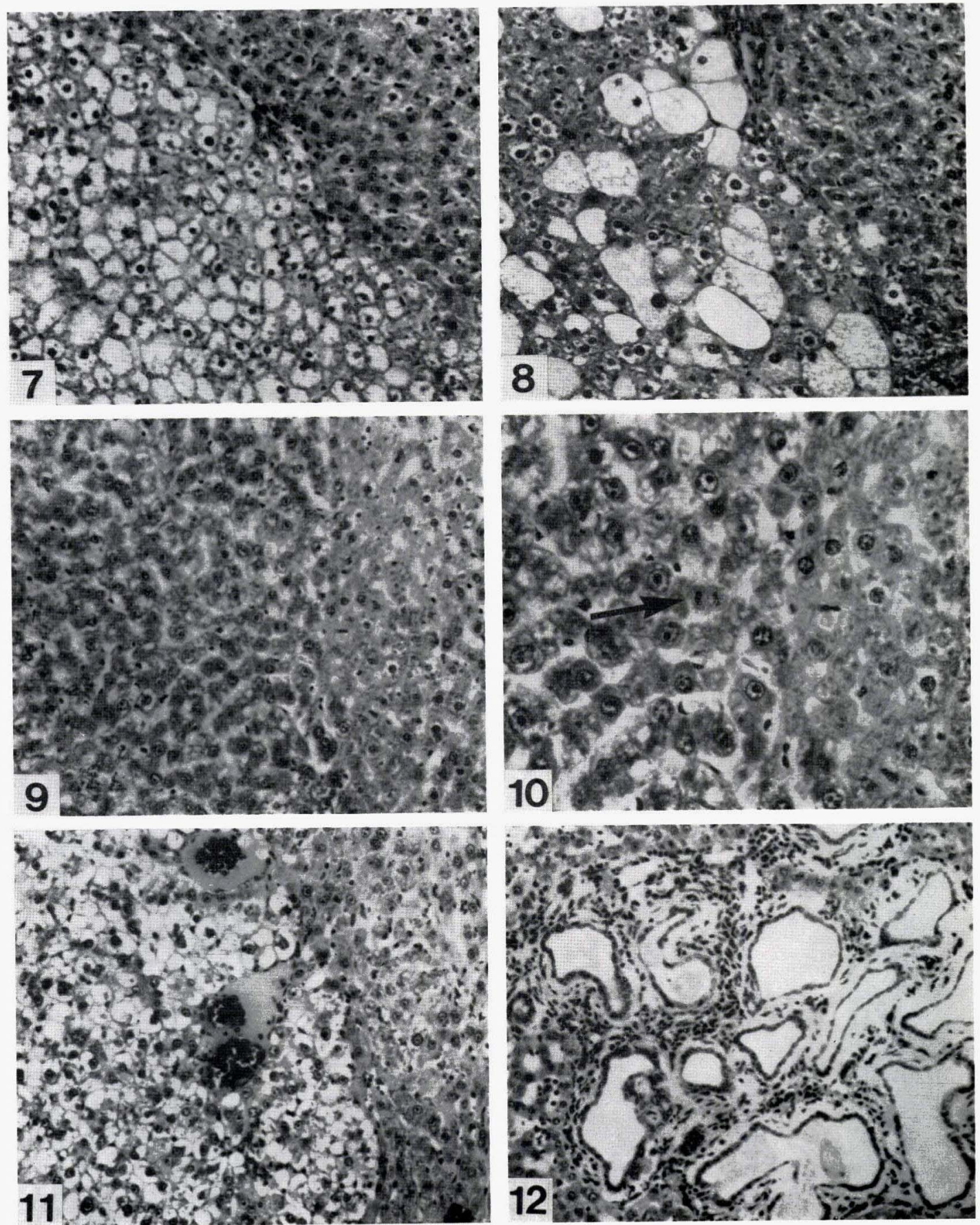